\title{
A Fresh Look at Followership: A Model for Matching Followership and Leadership Styles
}

\author{
Kent Bjugstad \\ Comcast Spotlight \\ Elizabeth C. Thach, Karen J. Thompson, and Alan Morris \\ Sonoma State University
}

\begin{abstract}
Followership has been an understudied topic in the academic literature and an underappreciated topic among practitioners. Although it has always been important, the study of followership has become even more crucial with the advent of the information age and dramatic changes in the workplace. This paper provides a fresh look at followership by providing a synthesis of the literature and presents a new model for matching followership styles to leadership styles. The model's practical value lies in its usefulness for describing how leaders can best work with followers, and how followers can best work with leaders.
\end{abstract}

\section{Introduction}

Followership has been an understudied discipline. As far back as 1933, management scholar Mary Parker Follett advocated more research into a topic that she stated was "of the utmost importance, but which has been far too little considered, and that's the part of followers..." (1949, p. 41). The lack of attention in researching followers has changed little since Follett delivered her call to arms over 70 years ago. While some scholars are beginning to look more closely at followership, this trend is less evident in the mainstream business world. A book search on the Amazon.com website revealed 95,220 titles devoted to leadership (Bjugstad, 2004). Bjugstad's search on followership found just 792 titles, and the majority of those books focused on either spiritual or political followership. Overall, the ratio of leadership to followership books was 120:1. The lack of research and emphasis on followership relative to leadership in the business world is ironic considering that the two are so intertwined.

One of the reasons followers haven't been researched is that there is a stigma associated with the term "follower." Followership may be defined as the ability to effectively follow the directives and support the efforts of a leader to maximize a structured organization. However, the term "followership" is often linked to negative and demeaning words like passive, weak, and conforming. According to Alcorn (1992), followers have been systematically devalued and, for many, the very word itself conjures up unfavorable images. This stereotype has caused people to avoid being categorized as followers. Research done by Williams and Miller (2002) on more than 1,600 executives across a wide range of industries indicated that over one-third of all executives are followers in some fashion. Yet, rarely did any of the executives concede that they were followers. The statement 
"Always be a leader, never a follower!" has gone a long way toward adding to the stigma of being a follower.

Another reason there is so little research on followership arises from a misconception that leadership is more important than followership. The assumption that good followership is simply doing what one is told, and that effective task accomplishment is the result of good leadership, doesn't amplify the merits of the follower role. According to Meindl (1987), management and organizational behavior have been dominated by the concept of leadership, which has assumed a romanticized, larger than life role as a result.

Organizational literature is full of studies of leadership characteristics, reflecting the belief that good or bad leadership largely explains organizational outcomes. In spite of its obvious relevance to leadership, followership is rarely discussed when corporations seek to better themselves. Instead, the focus turns to developing leadership skills. Much attention is paid to what makes a leader successful because the thinking is that as the leader succeeds, so does the organization. However, this view ignores the fact that leaders need followers to accomplish their goals.

It does seem ironic that the effectiveness of a leader is to a great extent dependent on the willingness and consent of the followers. Without followers, there can be no leaders. Indeed, Hansen (1987) advanced that active followership means the leader's authority has been accepted which gives legitimacy to the direction and vision of the leader. Without the eyes, ears, minds, and hearts of followers, leaders cannot function effectively. Similarly, Depree (1992) asserted that leaders only really accomplish something by permission of the followers.

Changes in the workplace also highlight the need for examining followership in more depth. The traditional organizational hierarchy between leaders and their followers has eroded over time thanks to expanding social networks and the growing empowerment of followers through their ability to access information more easily (Cross \& Parker, 2004; Brown, 2003). For example, employees now have access to information about their company and its competitors via the Internet that they were never privy to in the past. As Brown (2003) observed, leaders are "no longer the exclusive source of vital information about their companies or fields; therefore they can no longer expect to be followed blindly by their now well-informed, more skeptical ranks" (p. 68). Furthermore, the incidents at such companies as Enron, WorldCom, and Adelphia have led followers to question and distrust top leadership. Mergers, acquisitions, and downsizing have also accounted for more jaded followers. In addition, Maccoby (2004) stated that "the changing structure of families - more single-parent homes, dual working parents, and so on - have begun to create work environments where people value traditional leaders less" (p. 79). Perhaps this coincides with the decline in respect for authority figures in general. Whatever the reason, these changes signal the need to reevaluate the tendency to focus on leadership to the exclusion of followership. 
Many leaders have realized that developing their followers' skills is critical for creating high performance organizations. These developmental approaches come with a variety of names - total quality management, team building, quality of work life, job enrichment, reengineering, empowerment, management by objectives, etc. Lawrence and Nohria (2002) stated that organizations that fail to develop their workforces may not be competitive in the future. As the cost of intellectual capital increases, it is critical to have a supply of talented followers (Citrin, 2002). The old saying, "People are our most important asset" has never been more true.

While the industrial age was characterized by a rigid command-and-control structure, the advent of the information age has highlighted the need for more flexible leader-follower relationships. These changes have made the study of followership increasingly necessary as organizations seek new ways to select, train, and lead followers for maximum productivity. Flexibility is a key ingredient for both leaders and followers when it comes to their overall approach to work.

This paper aims to reignite the dialogue on followership and provide some practical applications of followership. First, we will review the current literature on followership. Then, we will acquaint the reader with two current models: one of followership and one of leadership. Finally, these distinct models will be used as the basis for a new hybrid model that integrates leadership styles and followership styles. This integrated model proposes how leaders and followers can best work together.

\section{Review of the Followership Literature}

The literature on followership can be categorized into three broad theoretical areas. These areas examine follower motivations, follower values and trust, and the characteristics of effective and ineffective followers.

\section{Follower Motivations}

A follower's motivation is a function of environmental and internal factors. To increase follower motivation, a company needs to create a results-oriented environment with genuine concern for its followers and provide performancerelated feedback. Today's follower-leader relationships show that followers want trust and are not motivated by what leaders think they would want, but rather by what each specific follower wants (Bain, 1982). According to Hughes (1998), followers motivate themselves. Motivation is generated internally, and a leader merely taps into the internal power of the follower. When a leader communicates trust and respect for followers' abilities to perform and achieve, the internal motivation of the followers takes over and drives them to succeed. Followers determine their commitment to the organization (and therefore their motivation) by reflecting on how hard they will work, what type of recognition or reward they might receive, and if that reward will be worth it (Strebel, 1996).

Motivation may also depend on the relationship between the follower and leader and how well their personal characteristics match up. If there is a similarity in 
values and beliefs between the follower and leader, the motivational need for empowerment may not be as high because the follower is driven by the bond with the leader (Mumford, Dansereau, \& Yammarino, 2000). The research on charismatic leadership suggests that followers' self-concepts may also be relevant in determining their motivations to follow certain leaders (Howell and Shamir, 2005).

A key to motivating followers is the concept of having them realize how important their function is in a broad sense. Blanchard and Bowles (1998) relate the story of what was considered a meaningless job - dishwashing at a college cafeteria:

“Dishwashing in a college cafeteria - it just doesn't get more important than that...think of the impact those students were going to have on the world. Business leaders, doctors, social scientists, world leaders, researchers. One load of unclean, bacteria-infected dishes could have wiped out a whole class. Look at it in terms of human impact...Students arrived tired, hungry, and likely lonely. You were an important part of the chain that provided joy and nourishment... What a wonderful gift to give another human being..." (p. 33).

Of course, some followers are motivated primarily by ambition. According to Kelley (1988), this type of person only uses followership to further his or her own ambitions.

Springboarding off of Vroom's expectancy theory (1964), Green (2000) discussed three conditions that must exist for followers to be highly motivated. First, they must have the confidence that they can do the job expected of them. Then, trust is needed in their leader to tie outcomes to performance. Lastly, the followers need satisfaction with the outcome(s) they receive. If performance falls short, there is a good probability that one of these three conditions is not being fully met. Common causes for a follower's lack of confidence ("I can't do it") could be inadequate skills, or unrealistic or unclear expectations. More training and the clarification of expectations are two ways to handle these problems. Tying outcomes to performance can easily solve the second condition. If the outcomes aren't satisfying to followers because they aren't finding the work itself rewarding, it might be worth investigating whether that position is matching the skills, interests, and needs of both the follower and the leader.

\section{Follower Values and Trust}

Values are instrumental in determining follower preferences for different types of leaders. Followers' values, in addition to other personal characteristics, can influence both their own effectiveness and the climate in which they work (Hanges, Offerman, \& Day, 2001). Followers and leaders work together better when they are comfortable with each other, and value congruence is one way to achieve common ground. When leaders effectively model their values, identity, emotions, and goals to their followers, the potential for authentic followership increases (Gardner et al., 2005). 
Along these lines, Ehrhart and Klein (2001) examined the follower-leader relationship to determine the influence of values and personality. The results indicated that (1) followers had different responses to the same leader behaviors, and (2) followers looked for leaders whose values matched their own. Followers who were achievement-oriented and risk takers preferred the charismatic leader, as did followers who liked to participate in decision making. According to Ehrhart and Klein, charismatic leaders helped followers satisfy their need for involvement and accomplishment by letting followers take an active role in decision making. Followers who valued interpersonal relations matched up with relationshiporiented leaders who could meet some of their interpersonal needs. Followers who valued achievement and structure were the best match for task-oriented leaders, because they provided stability and security.

The foundation of a productive follower-leader relationship is mutual trust. In a healthy organization, followers trust leaders to act in their best interest. In a three-year survey of 7,500 workers, Froggatt (2001) found that companies with employees who reported high levels of trust in their leaders had a 108 percent three-year return to shareholders. Conversely, companies with employees reporting low trust levels in leadership only had a 66 percent return.

\section{Effective Followers versus Ineffective Followers}

A few researchers have examined the characteristics of followers in an attempt to pinpoint what distinguishes good followers from bad ones. Kelley (1988) proposed that there are four essential qualities that effective followers share. First, effective followers manage themselves well. This quality refers to the ability to determine one's own goals within a large context and to decide what role to take at any given time. Secondly, effective followers are committed to the organization and to a purpose beyond themselves. Thirdly, effective followers build their competence and focus their efforts for maximum impact. They strive to reach higher levels of performance and expand themselves. Finally, effective followers are courageous, honest, and credible. This implies and requires independent and critical thinking skills as well as the ability to feel comfortable with others. Kelley also stated that an effective follower exhibits enthusiasm, intelligence, and self-reliance.

One of the most important characteristics of an effective follower may be the willingness to tell the truth. As the quantity of available information has increased exponentially, it has become imperative that followers provide truthful information to their leaders. Good followers speak up even to the point of disagreeing with their leaders. According to Bennis (2000), the irony is that the follower who is encouraged and is willing to speak out shows what kind of leadership the company has instituted. This tendency to speak up was also supported in research of followership and federal workers (Gilbert \& Hyde, 1988). Not only is it important for the organization to know what followers think, but effective leaders also need to respect followers who will speak up and share their points of view rather than withhold information. Ineffective followers fail to give honest opinions. They cover up problems and are inclined to become 'yes men.' If a 
company is going down the wrong road, it can get there faster if there are no followers informing the leaders that they took a wrong turn.

Chaleff (1995) claims that effective followers are cooperative and collaborative, qualities that are essential to all human progress. They think for and manage themselves and carry out duties with assertiveness and energy. For example, championship-level sports teams are composed of followers who know when to follow the game plan and when to innovate and think for themselves. Effective followers are well-balanced and responsible human resources who can succeed without strong leadership because they are committed to a purpose, principle, or person outside themselves. Kelley's (1988) research also found that many followers believe they offer as much value to organizations as leaders do.

Effective followers are distinguishable from ineffective followers by their enthusiasm and self-reliant participation in the pursuit of organizational goals. According to Blackshear (2003), "the 'ideal' follower is willing and able to help develop and sustain the best organizational performance" (p. 25). Ineffective followers are often critical, cynical, apathetic, and alienated; many will only do what is specifically requested of them. Instead of figuring out what they can do, ineffective followers focus on what can go wrong and what is beyond their control (Helmstetter, 1998). They tend to doubt themselves and, because they dwell on problems rather than solutions, they most often see their fears materialize.

According to Nelson (2001), they become experts at the "the blame game," blaming everybody around them for problems. These attitudes gradually spread to other departments, and the result is low morale, lack of production, and lost human potential (Ludin \& Lancaster, 1990).

\section{Models of Followership and Leadership}

To bring together the research on followership and leadership, a model was chosen from each area. The first model is Kelley's (1992) followership model which categorizes followers according to dimensions of thinking and acting. The second model is drawn from Hersey and Blanchard's (1982) situational leadership theory which categorizes leadership style based on the degree of relationship-oriented and task-oriented behavior displayed by the leader.

\section{Kelley's Model of Followership}

Kelley (1992) categorized followers according to the dimensions of thinking and acting. Followers who are independent, critical thinkers consider the impact of their actions, are willing to be creative and innovative, and may offer criticism. Dependent, uncritical thinkers only do what they are told and accept the leader's thinking. The second dimension, acting, is used to determine what sense of ownership the follower demonstrates. An active follower takes initiative in decision making, while a passive follower's involvement is limited to being told what to do. Despite the fact that Kelley created five different subsets of followers with the fifth subset (pragmatists) encompassing some of the characteristics of the other four, this analysis will only use the standard four-quadrant subset based 
on Kelley's definitions (Figure 1). This will enable the use of clear-cut distinctions between follower types.

The following is a summary of the behavioral characteristics of the four follower types (from Kelley, 1992):

Alienated followers are mavericks who have a healthy skepticism of the organization. They are capable, but cynical.

Conformist followers are the "yes people" of the organizations. They are very active at doing the organization's work and will actively follow orders.

Passive followers rely on leaders to do the thinking for them. They also require constant direction.

Exemplary followers are independent, innovative, and willing to question leadership. This type of follower is critical to organizational success. Exemplary followers know how to work well with other cohorts and present themselves consistently to all who come into contact with them.

Figure 1: Kelley's different types of followers

Source: Kelley (1992)

Independent, critical thinking

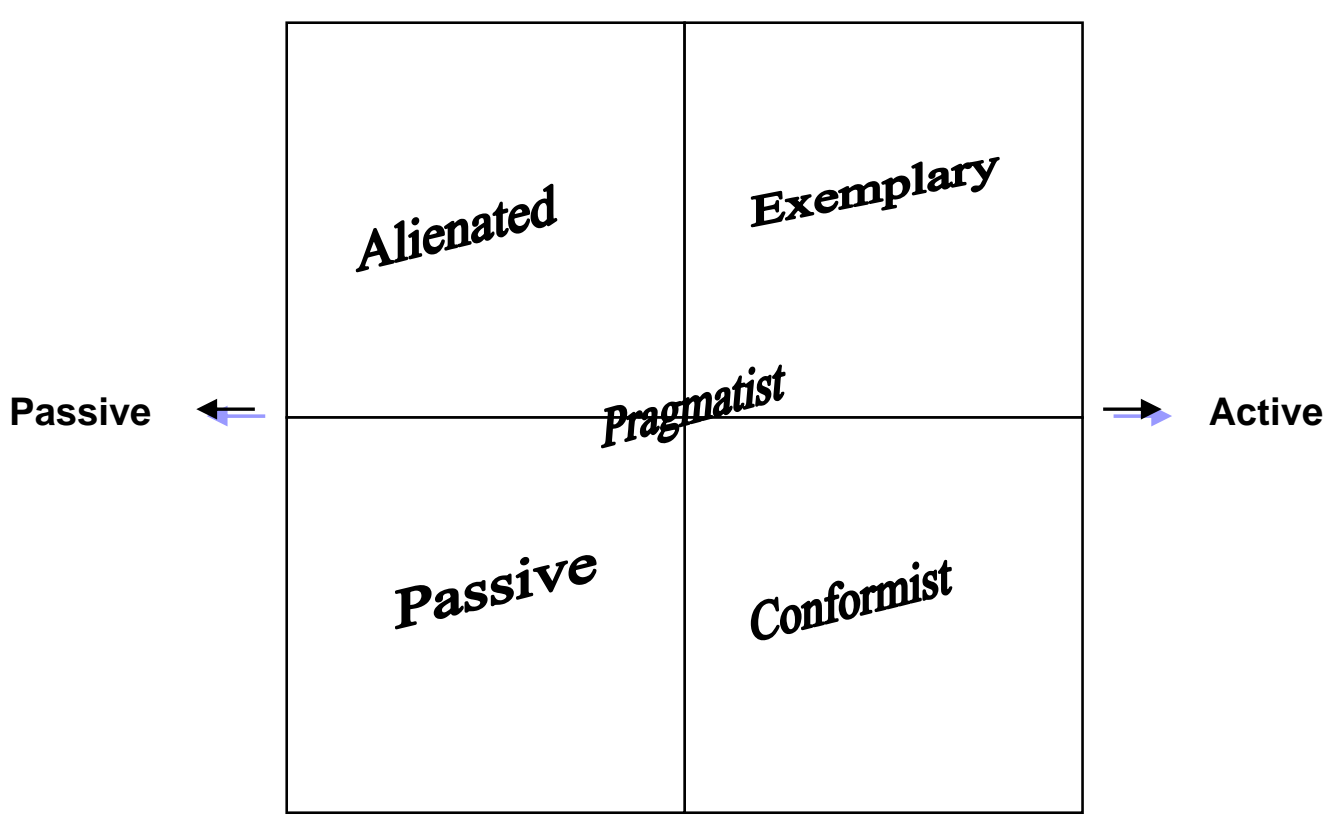

Dependent, uncritical thinking

This model may seem to impose some artificial rigidity on follower behavior, but followers typically can move from one quadrant to another just as leaders' styles can vary depending on the situation. It is typical to think of leaders as having a dominant style, and we will assume that to be true for followers also. 


\section{Hersey and Blanchard's Situational Leadership Theory}

Hersey and Blanchard's (1982) situational leadership theory argued that successful leadership is achieved by selecting a style based on follower readiness. The leader is directed to adopt one of four styles based on the degree of relationship- and task-oriented behavior required by the situation. For the purposes of this paper, the four styles will be viewed as static within the quadrants of this two dimensional model, although they are often treated as a continuum of sorts (Figure 2). The four leadership styles consist of Telling, Selling, Participating, and Delegating.

The following is a summary of the four leadership styles developed by Hersey and Blanchard (Hersey, 1984):

Telling should be used in situations in which followers lack the training, confidence, or desire to complete a task. The theory recommends that taskoriented leader behaviors should predominate in this case. Leaders need to direct followers down the right path by giving them detailed directions and monitoring their performance.

Selling is the style to use with followers who are confident and willing, but who are not able to complete the task. High levels of both task- and relationshiporiented behaviors are recommended in this situation. Leaders can guide follower behavior by clarifying decisions and giving followers the chance to ask questions.

Participating should be used to boost the motivation of followers who have the capabilities to achieve goals, but who lack confidence in themselves.

Relationship-oriented leadership predominates in this case. Leaders encourage followers to participate in decisions and support their efforts.

Delegating is the style to use when followers are able, confident, and motivated. Only low levels of relationship- and task-oriented behaviors are called for in this case as the follower is so self-directed. The leader can turn over responsibility to the follower in terms of what to do and how to do it. 
Figure 2: Hersey and Blanchard's Situational Leadership Quadrants Source: Hersey and Blanchard (1982)

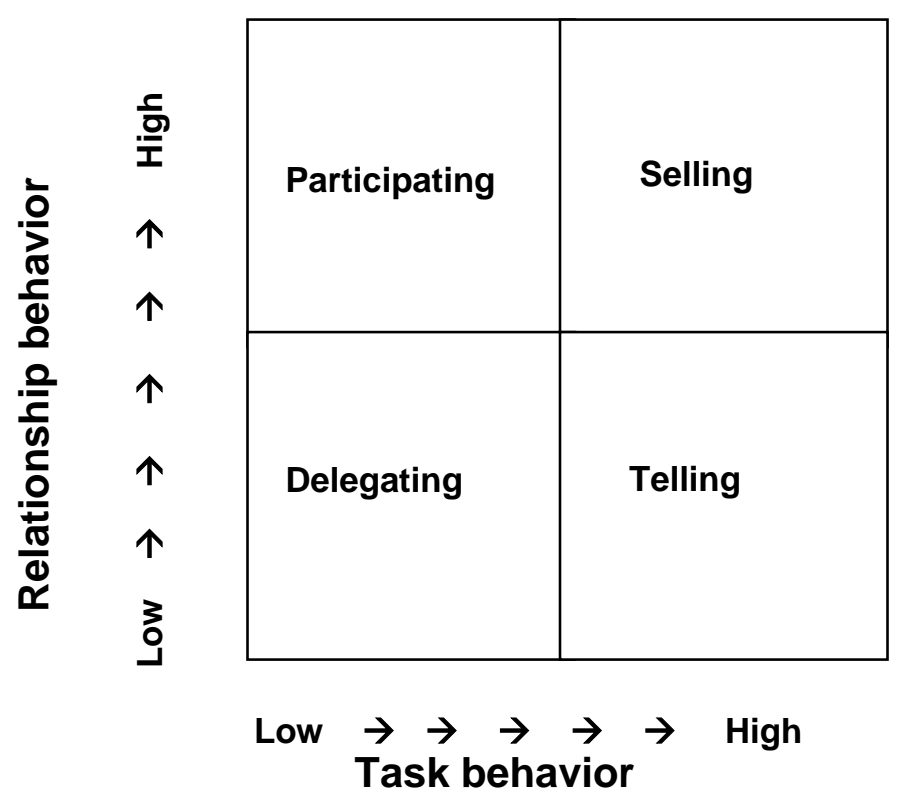




\section{An Integrated Model of Followership and Leadership Styles}

The final goal in this paper is to integrate the two models described above. The idea is to show how followership and leadership research can be combined for practical purposes, most specifically to increase follower productivity. Simply overlaying Kelley's four quadrants from Figure 1 onto Hersey and Blanchard's model in Figure 2 doesn't provide maximum productivity because a passive follower will not excel with a delegating leader. Along those same lines, an exemplary follower does not need a selling type of leader. By interchanging these two quadrants, however, as shown in Figure 3, the roles of both the leader and the follower can be maximized.

Figure 3: Integrated model of followership and leadership styles

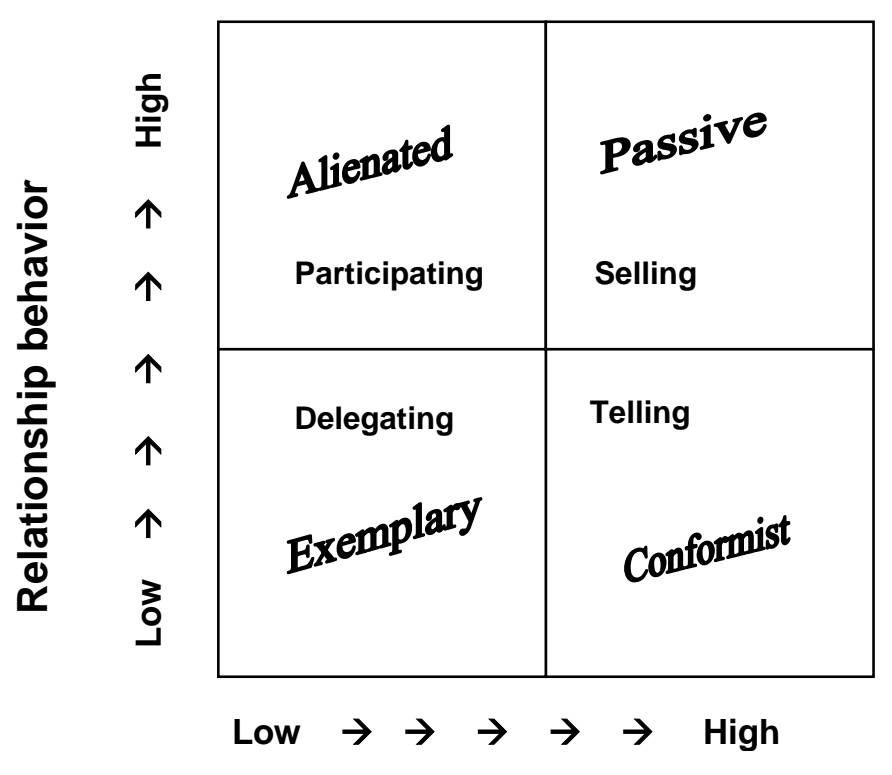

Task behavior

The participating style, in which a leader shares ideas and facilitates the decision making process, seems to fit best with alienated followers. The idea is to get these disillusioned followers to take a more active role, so they feel more involved in the organization. Alienated followers are capable, but need more consideration to create mutual respect and trust and to eliminate some of their cynicism. The selling style is arguably a good match for the passive follower, who needs direction and guidance. With the leader's support, passive followers can enhance their production, as well as receive encouragement. Conformist followers with their "will do as told" attitude can be placed in the telling style quadrant, which characterizes a leadership style that focuses on providing specific instructions and closely monitoring performance. Exemplary followers can be positioned in the delegating style quadrant where the leader turns over 
responsibility for decisions and implementation. Exemplary followers are up to the challenge of this category and should flourish to the benefit of the organization. By meshing the styles of leaders and followers, organizations can maximize the strengths and minimize the weaknesses of leader-follower relationships. Figure 4 displays recommended behaviors for leaders and followers in each quadrant of the new model.

Followership plays a vital role at every level of an organization. Furthering the effectiveness of followers requires doing away with the misconception that leaders do all of the thinking and followers merely carry out commands. These misconceptions can become self-fulfilling prophecies and organizations can rely too much on leaders. This model provides the framework to alleviate those misconceptions. As the model indicates, followers engage in different levels of critical thinking, and these can be matched with appropriate leaders.

Furthermore, in each quadrant, there needs to be some flexibility for both the leader and the follower. This stretching will cause growth for the individuals and for the organization.

Figure 4: Behaviors recommended for optimum matching of styles

\begin{tabular}{|l|l|l|l|}
\hline \multicolumn{1}{|c|}{$\begin{array}{c}\text { Leadership } \\
\text { Quadrant }\end{array}$} & $\begin{array}{l}\text { Leader Behaviors } \\
\text { Recommended }\end{array}$ & $\begin{array}{l}\text { Follower Behaviors } \\
\text { Recommended }\end{array}$ & \multicolumn{1}{c|}{$\begin{array}{c}\text { Followership } \\
\text { Quadrant }\end{array}$} \\
\hline Participating & $\longrightarrow \begin{array}{l}\text { The inclusion of } \\
\text { followers in decision } \\
\text { making to cause } \\
\text { alienated followers to } \\
\text { take ownership }\end{array}$ & $\begin{array}{l}\text { Becoming more } \\
\text { involved through } \\
\text { participation. } \\
\text { Changing insider vs. } \\
\text { outsider mindset. }\end{array}$ & Alienated \\
\hline Selling & $\longrightarrow \begin{array}{l}\text { Explaining decisions } \\
\text { and clarifying } \\
\text { expectations to } \\
\text { engage passive } \\
\text { followers. }\end{array}$ & Doing as requested. & Passive \\
\hline Telling & $\begin{array}{l}\text { Detailing } \\
\text { expectations and } \\
\text { monitoring } \\
\text { performance to direct } \\
\text { conformist followers. }\end{array}$ & $\begin{array}{l}\text { Showing that results } \\
\text { are important. }\end{array}$ & Conformist \\
\hline Delegating & $\begin{array}{l}\text { Turning over } \\
\text { decision making } \\
\text { responsibility and } \\
\text { implementation. }\end{array}$ & $\begin{array}{l}\text { Demonstrating } \\
\text { results with } \\
\text { increased } \\
\text { responsibility. }\end{array}$ & Exemplary \\
\hline
\end{tabular}




\section{Discussion and Application}

As we have seen, the follower-leader relationship does not operate in a vacuum. Leaders sometimes function as followers, and followers sometimes function as leaders. As leaders daily move back and forth between the two roles, this makes it even more imperative that the study of followership continues. Followers and leaders are linked together in interrelated roles and are dependent on each other. Clearly, the importance of followers cannot be underestimated. While organizations continue to devote time and money to the development of leadership, followership is what enables that leadership the opportunity to succeed. The legendary UCLA basketball coach, John Wooden, is quoted by Buckingham and Coffman (1999) as saying...

"No matter how you total success in the coaching profession, it all comes down to a single factor - talent. There may be a hundred great coaches of whom you have never heard... who will never receive the acclaim they deserve simply because they have not been blessed with the talent. Although not every coach can win consistently with talent, no coach can win without it" (p. 105).

This passage speaks about team sports, but the theme of "talent" is analogous to followers in an organization. Creating the right environment and developing followers into high performers should be a primary objective of every organization. This argument is supported by research that has examined follower effectiveness in relation to situational favorability (Miller, Butler, and Cosentino, 2004). Building relations with followers fosters the highest level of organizational commitment (Ellis, 2004), which helps to create a unified organization. Also, organizational commitment is positively related to job productivity and negatively related to both absenteeism and turnover (Robbins, 2005).

The integrated model of followership and leadership styles can be applied and matched to fit different organizational cultures and goals. Organizations may tend to have certain predominant leader and/or follower types, and so the specific organization will have to fit the two types together. It may be useful for organizations to experiment with the differences between the various types of leader and follower for short periods of time to observe productivity levels. Once that information has been analyzed, it should guide future research on how best to continue matching leader and follower styles. The optimal way to test how the integrated model would benefit the organization is to conduct the research in a controlled environment where all the variables are equal. This application of the model can then be better examined for the appropriate matching of particular styles. There may be an instance, for example, where a follower with dominant conformist characteristics might be more productive with a leader who exhibits strong selling attributes, instead of the traits of a telling leadership style. The model is flexible enough to allow for adjustments in the match-ups of followers and leaders. 


\section{Limitations of the Model}

While this integrated model of followership and leadership styles makes sense from an intuitive standpoint, there is little evidence to support it. Research will need to be done to test its propositions. Also, while leaders and followers often have a dominant style, they do not tend to use one style in all situations. Thus, the environment can skew the results of the quadrant match-ups that we propose. Furthermore, the matching of leaders and followers does not imply that leaders will only hire followers who work and think in their own image to make them feel more comfortable (Chatman, 1991). It does, however, raise the possibility of groupthink (Janis, 1982). Having either differing viewpoints or similar styles, however, has not revealed any consistent effects on performance (Lau \& Murnighan, 1998). With that in mind, this model needs to be implemented and studied further to validate the projected increase in productivity.

Another issue in the future study of matching followers to leaders is to isolate the variables that might alter the results. For example, will all leaders be given the same type of direction in working with followers and vice-versa? All of this research can come at a cost to organizations that are not willing to risk possible short-term pains for long-term gains.

\section{CONCLUSION}

This paper and the matching of followership and leadership styles reinforce themes identified in the literature on the relationships between followers and leaders (Cole, 1999; Goffee \& Jones, 2001; Chaleff, 1995; Ehrhart \& Klein, 2001; Cunningham \& MacGregor, 2000; Hanges et al., 2001; Mumford et al., 2000). By implementing an integrated model of followership and leadership styles, as well as linking the purpose to strategic organizational goals, leaders should become more effective because of their improved understanding of the follower-leader relationship. In addition, the increased commitment of followers should result in a talent bank for future leaders as followers are mentored by the leader in learning to match styles in working relationships. This paper provides a model that can satisfy the exchange between the leader and follower, resulting in a match that can provide more gratification to the parties involved and set the stage for higher performance. 


\section{REFERENCES}

Alcorn, D.S. (1992). Dynamic followership: Empowerment at work. Management Quarterly, 33, 9-13.

Bain, D. (1982). The productivity prescription. New York: McGraw-Hill. Bennis, W. (2000). Managing the dream: Reflections on leadership and change. Cambridge, MA: Perseus Books.

Bjugstad, K. (2004). Internet Book Search on Leadership and Followership. Retrieved October 15, 2004, from http://www.amazon.com.html.

Blackshear, P.B. (2003). The followership continuum: A model for fine tuning the workforce. Public Manager, 32(2), 25.

Blanchard, K., \& Bowles, S. (1998). Gung ho! New York: William Morrow and Company.

Brown, A. (2003). The new followership: A challenge for leaders. Futurist, $\underline{37}$, 68.

Buckingham, M., \& Coffman, C. (1999). First, break all the rules. New York: Simon and Schuster.

Chaleff, I. (1995). The courageous follower. San Francisco: Berrett-Koehler Publishers.

Chatman, J.A. (1991). Matching people and organizations. Administrative Science Quarterly, 36, 459-484.

Citrin, J.M. (2002). Zoom. New York: Doubleday Publishing.

Cole, M. (1999). Become the leader followers want to follow. Supervision, $\underline{60}$, 911.

Cross, R., and Parker, A. (2004). The Hidden Power of Social Networks. Boston: Harvard Business School Publishing.

Cunningham, J.B., \& MacGregor, J. (2000). Trust and the design of work: Complementary constructs in satisfaction and performance. Human Relations, $\underline{53}, 1575-1591$.

DePree, M. (1992). Leadership jazz. New York: Doubleday Publishing.

Ehrhart, M.G., \& Klein, K.J. (2001). Predicting follower's preferences for charismatic leadership: The influence of follower values and personality. Leadership Quarterly, 12, 153-179

Ellis, C. (2004). Leaders who inspire commitment. MIT Sloan Management Review, 45,5 . 
Follett, M.P. (1949). The essentials of leadership. London: Management Publications Trust, Ltd.

Froggatt, C.C. (2001). Work naked. San Francisco: Jossey-Bass Publishers.

Gardner, W.L., Avolio, B.J., Luthans, F., May, D.R., Walumbwa, F. (2005). "Can you see the real me?" A self-based model of authentic leader and follower development. Leadership Quarterly, 16, 343-372.

Gilbert, R.G., \& Hyde A.C. (1988). Followership and the federal worker. Public Administration Review, 48, 962-968.

Goffee, R., \& Jones, G. (2001). Followership: It's personal, too. Harvard Business Review, $\underline{79}, 148$.

Green, T. (2000). Motivation management. Palo Alto, CA: Davies-Black Publishing.

Hanges, P., Offerman, L., \& Day, D. (2001). Leaders, followers and values:

Progress and prospects for theory and research. Leadership Quarterly, 12, 129131.

Hansen, T.L. Jr. (1987). Management's impact on first line supervisor effectiveness. SAM Advanced Management Journal, $\underline{52}$, 41-45.

Helmstetter, S. (1998). The self talk solution. New York: Pocket Books.

Hersey, P. (1984). The management of organizational behavior: Utilizing human resources. Escondido, CA: Center for Leadership Studies.

Hersey, P. and Blanchard, K. (1982). Management of Organizational Behavior: Utilizing Human Resources. Englewood Cliffs, NJ: Prentice Hall.

Howell, J.M., \& Shamir, B. (2005). The role of followers in the charismatic leadership process: Relationships and their consequences. Academy of Management Review, 30(1), 96-112.

Hughes, M.L. (1998). Keeping your job while your bosses are losing theirs. Binghamton, NY: William Neil Publishing.

Janis, I.L. (1982). Groupthink. Boston: Houghton Mifflin.

Kelley, R. (1992). The power of followership. New York: Doubleday.

Kelley, R.E. (1988). In praise of followers. Harvard Business Review, $\underline{66}$, 142148.

Lau, D.C., \& Murnighan, J.K. (1998). Demographic diversity and faultlines. Academy of Management Review, 23, 325-340. 
Lawrence, P.R., \& Nohria, N. (2002). Driven: How human nature shapes our choices. San Francisco: Jossey-Bass Publishers.

Ludin, S., \& Lancaster, L. (1990). Beyond leadership...the importance of followership. Futurist, 24, 18-24.

Maccoby, M. (2004). The power of transference. Harvard Business Review, $\underline{82}$, 76-85.

Meindl, J.R. (1987). The romance of leadership. Administrative Science Quarterly, $\underline{30}, 91-108$.

Miller, R.L., Butler, J., \& Cosentino, C.J. (2004). Followership effectiveness: An extension of Fiedler's contingency model. Leadership and Organization Development Journal, 25(3/4), 362-368.

Mumford, M.D., Dansereau, F., \& Yammarino, F.J. (2000). Followers, motivations and levels of analysis: The case of individualized leadership. Leadership Quarterly, 11, 313-340.

Nelson, B. (2001). Please don't just do what I tell you. New York: Hyperion.

Robbins, S. P. (2005). Organizational Behavior. Upper Saddle River, NJ:

Pearson Prentice Hall.

Strebel, P. (1996). Why do employees resist change? Harvard Business Review, 74, 86-92.

Vroom, V.H. (1964). Work and motivation. New York: John Wiley.

Williams, G.A., \& Miller, R.B. (2002). Change the way you persuade. Harvard Business Review, $\underline{80}$, 65-73. 